DEPÓSITO LEGAL ZU2020000153

Esta publicación científica en formato digital

es continuidad de la revista impresa

ISSN 0041-8811

E-ISSN 2665-0428

Revista

de la

Universidad

del Tunlia

Fundada en 1947

por el Dr. Jesús Emrique Lossada

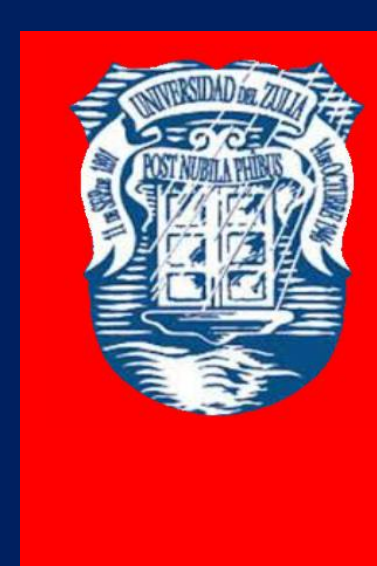

Ciencias

Sociales

y Arte

Aกัต 11 No 31

Septiembre - Diciembre 2021

Tercera ípoca

Maracailbo-Venezuela 


\title{
Implementation of the Third Mission of the Universities: Regional Aspect
}

\author{
Ekaterina G. Shumik* \\ Olga A. Baturina**
}

\begin{abstract}
National economic growth plays an important role in the education rate of society, since there is a strong connection between the success of the country and the level of development of human capital. In this sense, universities, as leaders of higher education, can powerfully affect the socio-economic development of society. In this article, the authors investigated different models of university development with the intention of determining the importance of their association. In addition, the authors evaluated the level and trends of the development of alliances between the universities of the Far Eastern Federal District (FEFD) as a tool for the implementation of their mission. To do this, they analyzed the websites of FEFD universities to reflect data on common activities within social activities. They also did a comparative analysis to compare the characteristics of the universities and evaluate the differences in the implementation of the social function. Finally, the correlation analysis was used to determine the effect of social events, the number of students and the university ranking. Based on these analyzes, it can be concluded that most of the universities are located in three regions: Primorsky and Khabarovsk Territories, as well as the Republic of Sakha (Yakutia), which are pioneers in terms of the number of students. While there is a tendency to reduce government involvement in university support, the FEFD increases. In addition, it has been shown that there is a relationship between the position in the ranking of universities in the region and the number of social events. Regarding the structure of university activities in matters of social responsibility, the development of university partnership interactions in the process of implementation of social responsibility has been verified, but the level of formalization of relationships is extremely low.
\end{abstract}

KEY WORDS: Far Eastern Federal District; College; University transformation.

${ }^{*}$ Candidate of Economical Science, Associate Professor of the Department of Economics and Management, Vladivostok State University of Economics and Service, 690014, Russia, Vladivostok, Gogolya Street, 41; https://orcid.org/0000-0003-4065-7798. E-mail: Kshumik@mail.ru

${ }^{* *}$ Candidate of Economical Science, Associate Professor of the Department of Economics and Management, Vladivostok State University of Economics and Service, 690014, Russia, Vladivostok, Gogolya Street, 41; https://orcid.org/0000-0003-2599-9095. E-mail: Olga.Ruban@vvsu.ru

Recibido: 14/07/2020

Aceptado: 10/09/2020 


\section{Implementación de la Tercera Misión de las Universidades: Aspecto Regional}

\section{RESUMEN}

El crecimiento económico nacional juega un papel importante en la tasa de educación de la sociedad, ya que existe una fuerte conexión entre el éxito del país y el nivel de desarrollo del capital humano. En este sentido, las universidades, como líderes de la educación superior, pueden afectar poderosamente el desarrollo socioeconómico de la sociedad. En este artículo, los autores investigaron diferentes modelos de desarrollo universitario con la intención de determinar la importancia de su asociación. Además, los autores evaluaron el nivel y las tendencias del desarrollo de alianzas entre las universidades del Distrito Federal del Lejano Oriente (FEFD) como una herramienta para la implementación de su misión. Para ello, analizaron los sitios web de las universidades FEFD para reflejar datos sobre actividades comunes dentro de las actividades sociales. También hicieron un análisis comparativo para comparar las características de las universidades y evaluar las diferencias en la implementación de la función social. Finalmente, se utilizó el análisis de correlación para determinar el efecto de los eventos sociales, el número de estudiantes y el ranking universitario. Según estos análisis, se puede concluir que la mayoría de las universidades están ubicadas en tres regiones: Territorios de Primorsky y Khabarovsk, así como la República de Sakha (Yakutia), que son pioneras en cuanto al número de estudiantes. Si bien existe una tendencia a reducir la participación del gobierno en el apoyo a la universidad, aumenta el FEFD. Además, se ha demostrado que existe una relación entre la posición en el ranking de las universidades de la región y el número de eventos sociales. En cuanto a la estructura de las actividades universitarias en materia de responsabilidad social, se ha comprobado el desarrollo de las interacciones del partenariado universitario en el proceso de implementación de la responsabilidad social, pero el nivel de formalización de las relaciones es extremadamente bajo.

PALABRAS CLAVE: Distrito Federal del Lejano Oriente; Universidad; Transformación universitaria.

\section{Introduction}

An important factor in national economic growth is the level of population education since the country's success directly depends on the level of human capital development. And in modern conditions, this mission is assigned to higher education, its quality level and focus. According to the State Program for the Development of Education, the creation of a network of institutions and organizations of higher education, corresponding to the conditions for the 
REVISTA DE LA UNIVERSIDAD DEL ZULIA. 3e época. Año 11 Nº 31, 2020 Ekaterina Shumik \& Olga Baturina /// Implementation of the Third Mission of the Universities...323-338 DOI: http://dx.doi.org/10.46925//rdluz.31.20

development of the knowledge economy, will contribute to the Russian education competitiveness increase.

In November 2018, during the international conference "The third mission of the university", the rector of Moscow State University named after M.V. Lomonosov V. A. Sadovnichy noted that "of course, education and science are traditionally in the focus of attention of universities. This is extremely important for Russia, because with such a large number of regions, the connection between universities and local communities is of particular importance. Universities need a reaction to the changes in the economy as a whole, an objective view of the region and the country development, and the transfer of knowledge between them."

\section{Theory}

Universities have a fairly long history, during which they play different roles in the socio-economic development of society (https://scientificrussia.ru). The authors examined various models of universities with the determination of partnership importance. The scholastic model of the University was the first stage of modern university development, theological faculties predominated. A university had a high degree of academic freedom and autonomy in decision making. Shmonin D.V (Shmonin, 2013) distinguishes consistency as the main fundamental feature of educational and scientific activity, which is also inherent in modern models, which makes it possible to ensure their consistent development. The universities of the period under review are aimed at the public good, do not support the idea of knowledge usefulness, that is, they are more theoretical than applied in nature.

The next stage of development is the emergence of a new model - research. According to the ideas of Humboldt (1998), K. Jaspers (2006), H. Ortega y Gasset (2010), the main tasks are the following: the search for truth during the research process, its transmission in the learning process and the upbringing of a person with high intellectual culture. Research is at the heart of the education process; there is the specialization of educational centers in individual disciplines.

The role of research universities at the initial stage was to ensure social mobility of society, training for promotion to the civil service, and the accumulation of scientific knowledge. This concept is reflected in the modern development of classical universities by 
REVISTA DE LA UNIVERSIDAD DEL ZULIA. 3e época. Año 11 Nº 31, 2020 Ekaterina Shumik \& Olga Baturina /// Implementation of the Third Mission of the Universities...323-338

DOI: http://dx.doi.org/10.46925//rdluz.31.20

the works of V.A. Sadovnichy (Sadovnichy et al., 1995), Krasnobaeva I.A. (2007), Prokopyev V.P. (2000), Zakharov I.V. (1994): they determine features, functions and the role in social life.

Schedrovitsky P.G. (www.bsu.edu.ru) highlights the features of this stage of university development for Russia: despite the fact that the European model of state control over activities was used, they had a high degree of autonomy, professors were almost civil servants.

The processes of accelerated industrialization have led to a change in the university role, they acquire a sectoral focus and are often subordinate to the relevant departments and ministries that have a significant impact on the training program, staffing requirements and the educational process.

This makes it possible to single out the sectoral model, which is typical for Russia: one of the basic principles of university functioning is the constant mutually beneficial relationship of higher education with industry (Russian school of education, 2017), the specification of the professional area, taking into account the sectoral focus. "Pure Science" was transferred to scientific organizations. There is a separation of the science organizations as such and education, which is demanded by the labor market.

Thus, the sectoral model of university development is characterized by autonomy reduction and dependence increase on external factors, in particular, the mechanisms of public administration of the higher education system, the manifestation and strengthening of the connection between education and profession. Changing the role of the university and the model of its development leads to education popularity and necessitates a change in the management paradigm.

The development of the knowledge economy, within which the role of knowledge in society changes, has led to the formation of the entrepreneurial university concept. B.R. Clark (2011) notes that one of the goals of its development is getting resistance and independence in the external environment. Particular attention is paid to the development of interaction with the external environment, its new forms are developing, especially in the field of financing activities. 
REVISTA DE LA UNIVERSIDAD DEL ZULIA. 3e época. Año 11 Nº 31, 2020 Ekaterina Shumik \& Olga Baturina /// Implementation of the Third Mission of the Universities...323-338 DOI: http://dx.doi.org/10.46925//rdluz.31.20

This concept was reflected in the works by G. Itskovits (2010), L. Leidesdorf (2006), M. Gibbons (1999), L.P. Kiyashchenko (2010), Grebenshchikova E.G. (2011), Kobzeva A.V., Uvarova A.F. (2004), and others through the triple helix model, where universities are given a central place in the regional innovative economic development and in the development of horizontal links between participants.

Atoyan V., Kazakova N. (2005) note the development of a modern university as a supporting structure, the main source and disseminator of knowledge. And knowledge is regarded as the main tool for high-efficiency provision and life quality improvement.

Based on the foregoing, the prerequisites for the development of the entrepreneurial model of universities are the development of the knowledge economy and, thus, a change of knowledge purpose in society, the popularization of higher education, the shortage of resources, the change in state and labor market requirements for the main role of universities. A special place in the model is occupied by partner interactions, without which its development is impossible. The most significant are the relations between universities, business and government (Martínez de Carrasquero, 2019). The main motives for interactions are diversification of funding sources, the introduction of knowledge into practical activities, teaching practice change, and overcoming of resource shortages, etc.

The evolution of university models reveals a high degree of strategic partnership relevance between various participants in the educational process and society.

\section{Study}

The authors assessed the level and trends of partnership development between the universities of the Far Eastern Federal District (hereinafter referred to as the FEFD) as a tool of their mission implementation.

The following methods were used to conduct the assessment:

- content - the analysis of the websites of the Far Eastern Federal District universities for the reflection of information on the implementation of joint activities in the framework of social activities within various areas of interaction;

- comparative analysis to compare the characteristics of universities and / or groups of universities in order to determine general trends and differences in the implementation of the social function; 
REVISTA DE LA UNIVERSIDAD DEL ZULIA. 3e época. Año 11 Nº 31, 2020 Ekaterina Shumik \& Olga Baturina /// Implementation of the Third Mission of the Universities...323-338

DOI: http://dx.doi.org/10.46925//rdluz.31.20

- correlation analysis to identify the mutual influence of the number of social events, the number of students and the university ranking.

The distribution of universities by the district is not uniform. The leaders are the Central, North-Western and Volga districts. At the end of 2018, more than 100 educational institutions of higher education operated in the Far Eastern Federal District, most of which are branches. There are 34 leading universities in the region, of which 6 are private. Figure 1 shows the characteristics of the leading universities of the Far Eastern Federal District according to three criteria: the number of universities in the region, the number of students and the proportion of students studying on a budgetary basis.

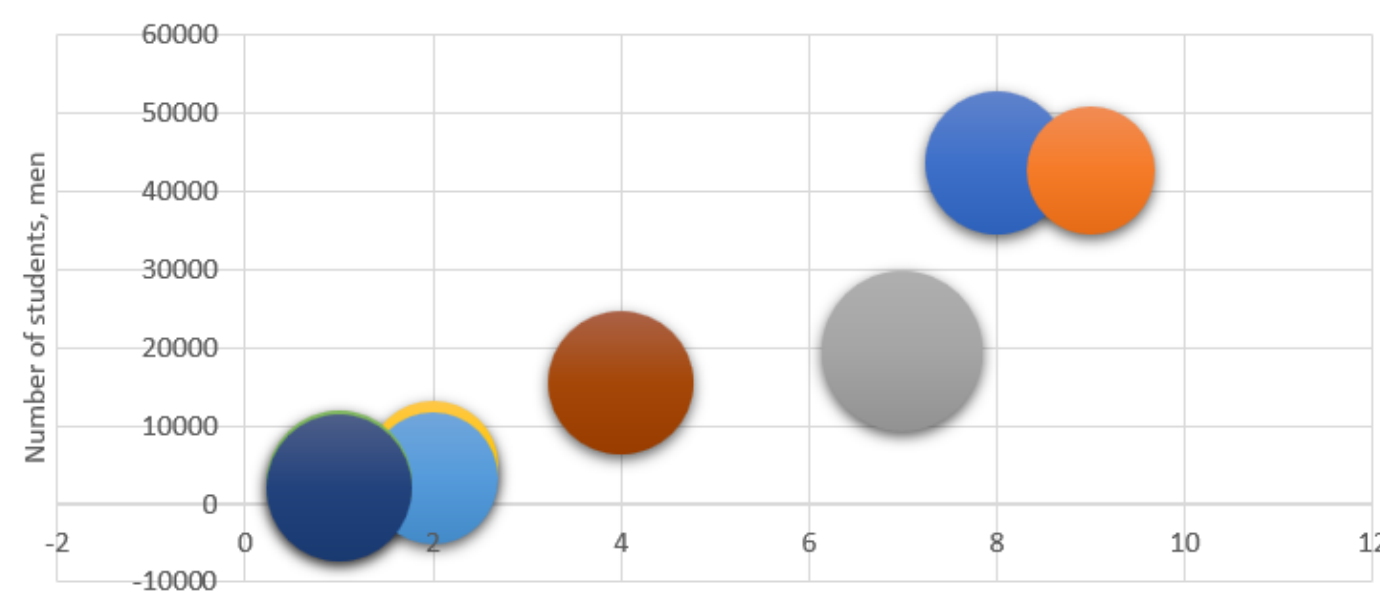

Number of universities in the region

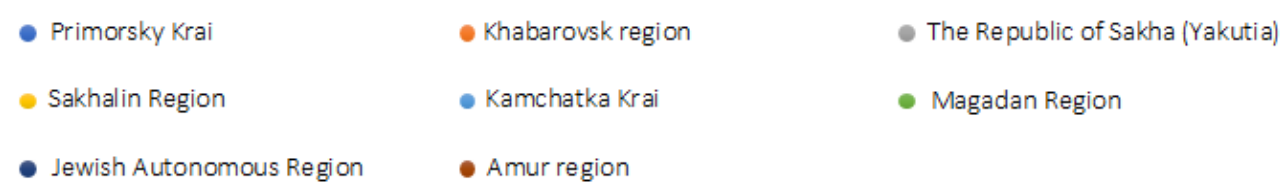

Figure 1. FEFD universities

Based on the data reviewed, we can conclude that the largest number of universities are located in three regions of the subject under consideration: Primorsky and Khabarovsk Territories, as well as the Republic of Sakha (Yakutia). They are also the leaders in terms of the number of students in general, however, the share of students studying at the expense of budgetary allocations is highest in Yakutia - about 74\%, followed by Magadan, Amur and Jewish Autonomous regions - about 60\%. 
REVISTA DE LA UNIVERSIDAD DEL ZULIA. 3e época. Año 11 Nº 31, 2020 Ekaterina Shumik \& Olga Baturina /// Implementation of the Third Mission of the Universities...323-338 DOI: http://dx.doi.org/10.46925//rdluz.31.20

It should be noted that despite the fact that recently there has been a tendency to reduce the state share in university financing within the Russian Federation, it increases in the Far Eastern Federal District. This is due to the fact that this constituent entity of the Federation is among the priority and strategically important for the Russian Federation's development.

On the one hand, partnerships between universities have recently become an object of assessment in various rating systems. This suggests that the quality of its implementation may affect the rating position.

Based on the foregoing, at the first stage, to assess the level of partnership development between universities at the regional level, the authors carried out the content analysis of university websites, including the assessment of the number of events within its implementation, its structure by participants and content.

The evaluation criterion is the presence of news content about the joint events held on the main website of a university and / or on the website of its structural divisions.

Figure 2 shows the comparison of a university rating position and the number of events within the framework of its social responsibility implementation reflected on its website. 
REVISTA DE LA UNIVERSIDAD DEL ZULIA. $3^{a}$ época. Año $11 N^{\circ}$ 31, 2020 Ekaterina Shumik \& Olga Baturina /// Implementation of the Third Mission of the Universities...323-338 DOI: http://dx.doi.org/10.46925//rdluz.31.20

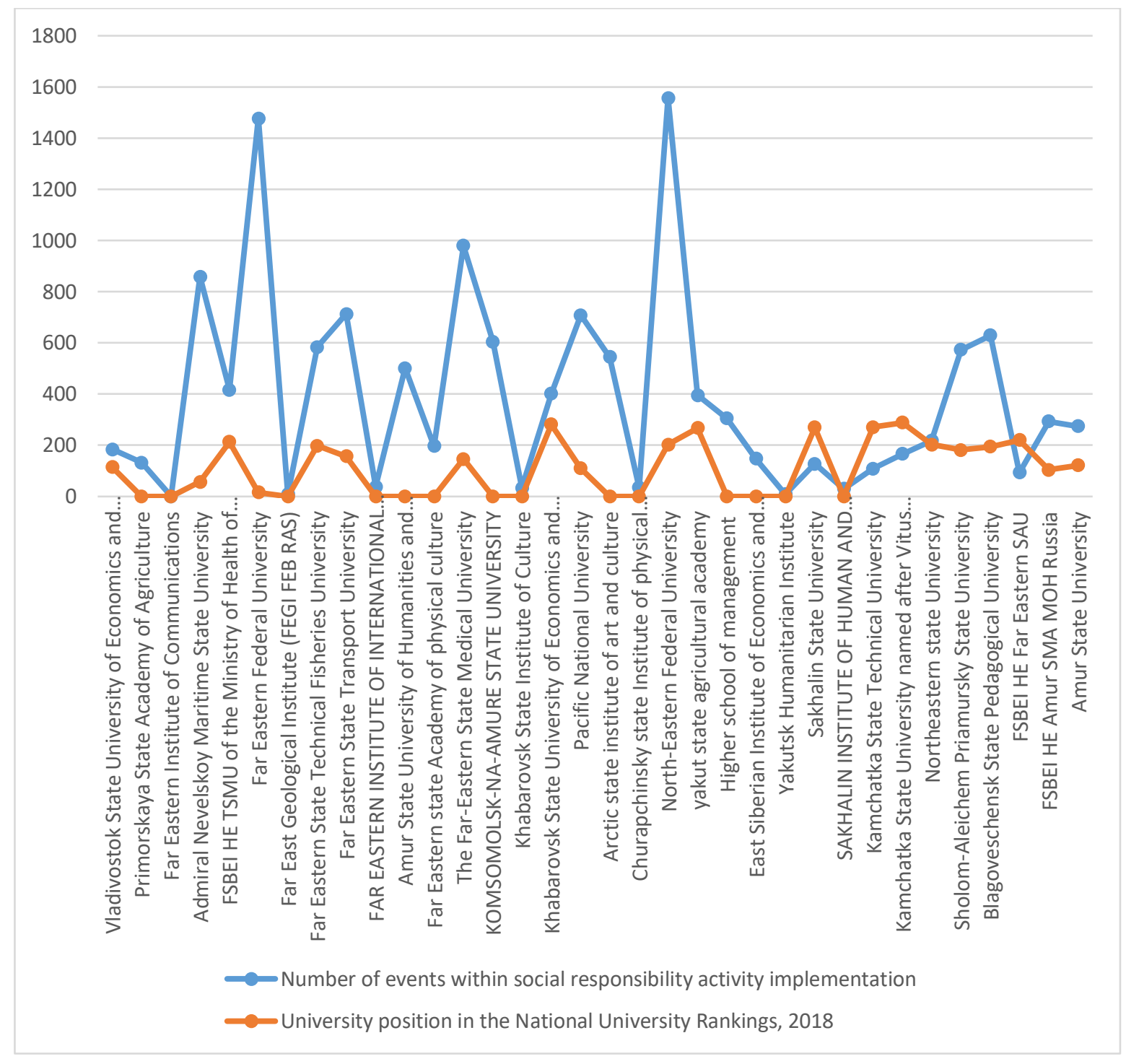

Figure 2. Comparison of the university rating position with the number of events within the framework of partnership implementation

It should be noted that for various reasons some universities are not represented in the ranking at the end of 2019. In general, a very close relationship between the two studied categories is visible, but it is impossible to assert a direct relationship. If we consider this ratio by region, then the following relationship is also traced: the average ranking position of universities in the region correlates with the number of social events presented on the website of the educational organization.

According to the event participants (the subjects of relations), the following were identified: regional authorities, municipalities, business structures, other universities, the 
REVISTA DE LA UNIVERSIDAD DEL ZULIA. 3e época. Año 11 Nº 31, 2020 Ekaterina Shumik \& Olga Baturina /// Implementation of the Third Mission of the Universities...323-338

DOI: http://dx.doi.org/10.46925//rdluz.31.20

organizations of secondary general and vocational education, non-profit organizations and others. In terms of relation implementation forms, the assessment was carried out in the context of joint events, meetings, joint projects, partnership agreements and others. Figure 3 shows the structure of activities in terms of their implementation form.

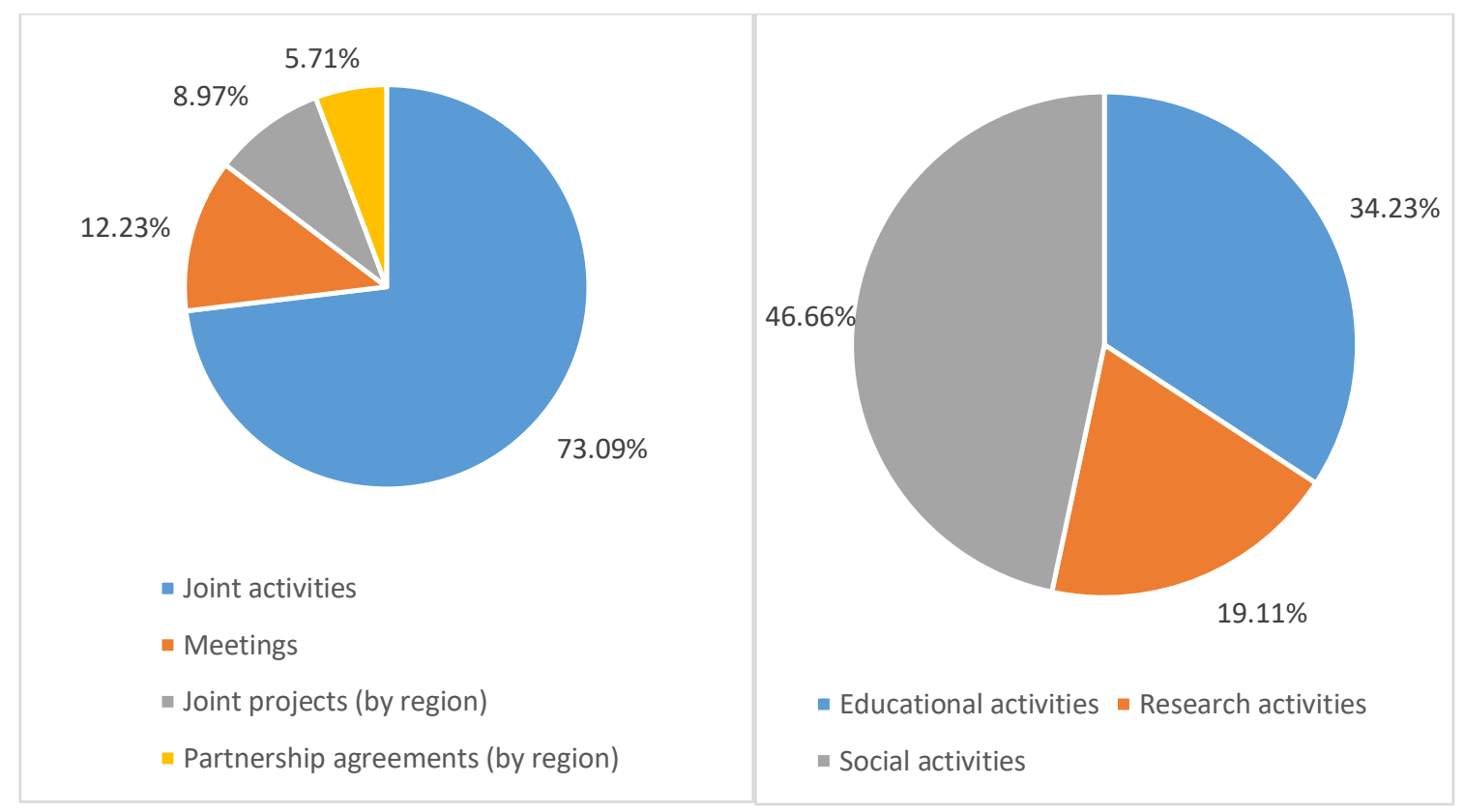

Figure 3. The structure of university activities in the framework of social responsibility implementation

The structure is dominated by joint events; this trend continues in the context of regions. This may indicate the development of university partnership interactions in the process of social responsibility implementation, but the level of relation formalization is extremely low (about 6\% of events take place within the framework of partnership agreement implementation).

Most of the events take place within the framework of the university social and educational activities. In educational activities, the university priority is the training and retraining of personnel needed by the region. There are many areas of university responsibility manifestation in social activities. These include employment of graduates, assistance to low-income citizens, socialization of students, implementation of legislation in the field of social support, organization of various kinds of sports and cultural events, including representation of the territory in various regional, All-Russian and international competitions. 
REVISTA DE LA UNIVERSIDAD DEL ZULIA. 3e época. Año 11 Nº 31, 2020 Ekaterina Shumik \& Olga Baturina /// Implementation of the Third Mission of the Universities...323-338

DOI: http://dx.doi.org/10.46925//rdluz.31.20

It should be noted that research activity requires strengthening: the development of high technologies, their introduction into scientific and practical activities, the provision of highly qualified personnel training - all this determines the university's responsibility to society. Next, let's consider the composition of university partners.

Based on the data obtained, it can be noted that the university conducts about $55 \%$ of the events with the participation of partners, and $45 \%$ of events - independently (the group "Others" on Figure 4).

Most often, regional authorities act as partners, and as the most interested participants. In terms of the forms of activities, these are "Joint activities" in the plane of social activity.

About 13\% of the activities are implemented jointly with other universities. It is also "Joint Events", but within the framework of educational activities.

The correlation dependence between the following characteristics was assessed at the second stage:

- "Number of events held"; (events)

- "Number of students studying" (student)

- "The rating of the university according to the agency INTERFAX 2018" (rank).

To perform the calculations, the authors made an assumption: the universities of the Far Eastern Federal District, which were not included in the National University Ranking 2019 (hereinafter the Ranking) were assigned a place following the last one in the Ranking for various reasons.

Data analysis was carried out using the RStudio program designed for statistical data processing and working with graphics in the R programming language.

Sample characteristics: 34 observations, the average rating of the universities represented was 241 points, the average number of students enrolled in the analyzed universities was 3966 people.

To obtain a general characteristic of the sample, the authors analyzed the relationship "events - student - rank" using the graphical method (Figure 5). 
REVISTA DE LA UNIVERSIDAD DEL ZULIA. 3e época. Año $11 N^{\circ}$ 31, 2020 Ekaterina Shumik \& Olga Baturina /// Implementation of the Third Mission of the Universities...323-338 DOI: http://dx.doi.org/10.46925//rdluz.31.20

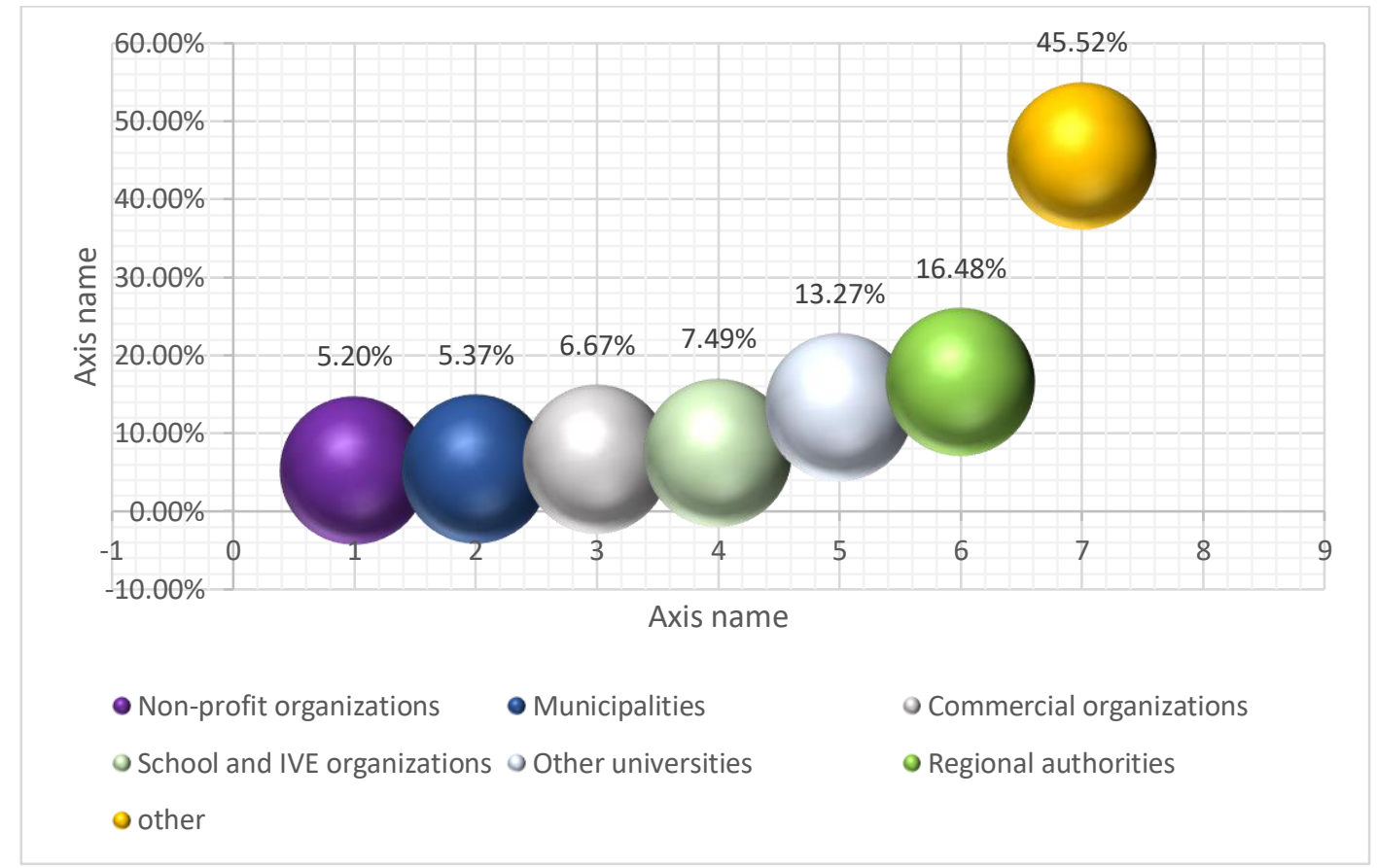

Figure 4. The structure of university partners

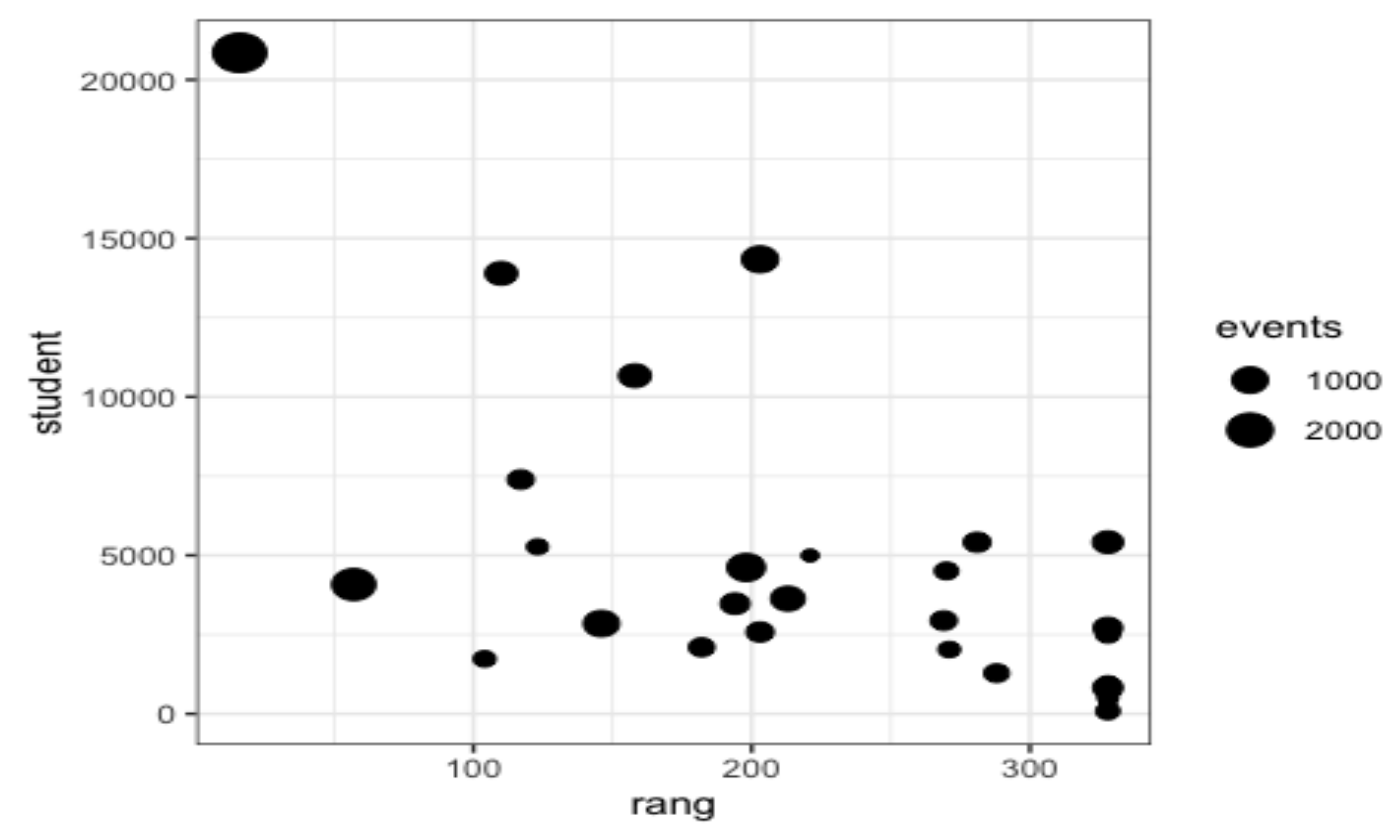

Figure 5. "Events - student - rank" relationship

Thus, the universities in the top positions of the Ranking (FEFU and VSUES) have the largest number of events, the universities in the ranking below 200 have about 1000 events held with partners. 
REVISTA DE LA UNIVERSIDAD DEL ZULIA. 3e época. Año 11 Nº 31, 2020 Ekaterina Shumik \& Olga Baturina /// Implementation of the Third Mission of the Universities...323-338

DOI: http://dx.doi.org/10.46925//rdluz.31.20

It is worth noting the correlation between the number of activities and the number of students. Next, we will consider the mutual influence of indicators among themselves in more detail.

-"Events - rank" relationship (Figure 6).

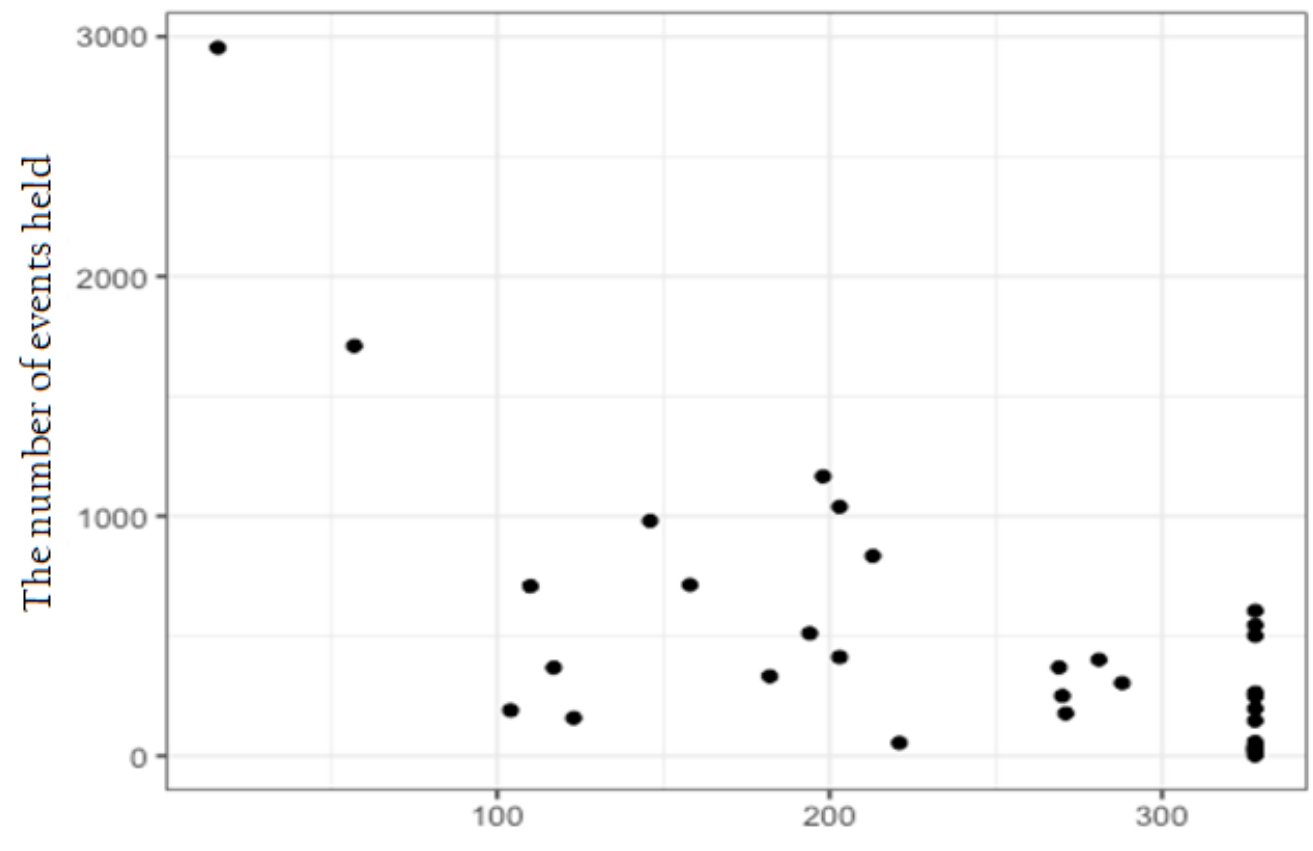

University ranking according to INT ERFAX 2018

Figure 6. «Events -rank» relationship

Based on the presented graphic data, it can be concluded that there is no linearfunctional relationship between two studied characteristics. Consequently, when they develop the rating, quantitative indicators of the university activity in the implementation of socially significant events for the region are not taken into account. As was presented above (Figure 4), most of the event takes place with the participation of regional authorities, defining the importance of the university in the region.

-"Events - student" relationship (Figure 8). 


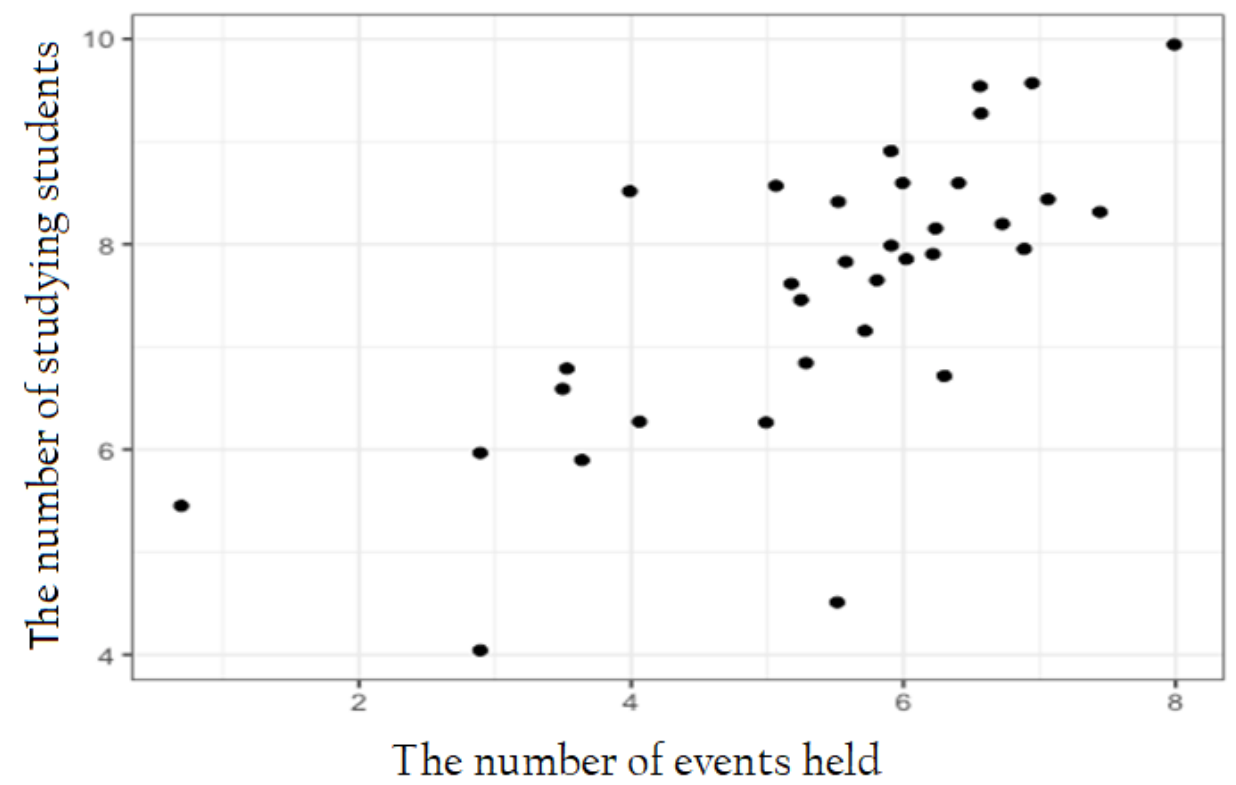

Figure 8. «Events - student» relationship

To obtain more accurate results of the analysis, taking of variable logarithm was performed, which made it possible to level the distortion of the equation regression in connection with far-apart mean data (FEFU) without excluding them from the study.

The graph shows a linear dependence of the number of students on the number of events held. Comparing the results of the event structure analysis, we can conclude that socially responsible universities attract more students at the regional level, and, consequently, extra-budgetary funds.

\section{Result and Discussion}

The problems of using the tools of the new public management in higher education and their impact on the activities of teachers are considered by N.V. Kurbatova (2014). The main transformations are the following: a change in remuneration system and labor relations with a focus on results, differentiation of universities, the introduction of performance indicators, and a change in the principles of financing.

The specifics of educational institutions when they use the principles of new public management are noted by V.I. Baydaenko and Selezneva N.A., in particular, the relations with students should not be developed only according to the "supplier-client" model (Baidenko \& Selezneva, 2011). 
REVISTA DE LA UNIVERSIDAD DEL ZULIA. 3e época. Año $11 N^{\circ}$ 31, 2020 Ekaterina Shumik \& Olga Baturina /// Implementation of the Third Mission of the Universities...323-338 DOI: http://dx.doi.org/10.46925//rdluz.31.20

One of the ways of the concept development is the network approach, which, according to A.V. Kurochkin, involves the actualization of the "co-management" concept (Kurochkin, 2005) as the most acceptable form of managerial influence. The advantage is the possible synergy effect resulting from joint actions. The integration of various participants into a network leads to the formation of multi-subject interactions, which are conditioned by the presence of strategic benefits from joint actions. Based on this, it follows that the formation of a partner network occurs on a voluntary basis and coercion (administrative or legislative) is unacceptable. In this case, networks are presented as "a highly developed form of social coordination and management concerning inter-organizational ties" (Mikhailova, 2015).

Thus, the open model of universities has the following fundamental characteristics: a high degree of openness and performance, a wide range of partners and the network nature of interactions with them.

\section{References}

Atoyan, V., \& Kazakova, N. (2005). Universities in modern society. Higher education in Russia, 4, 3-9.

Baidenko, V.I., \& Selezneva, N.A. (2011). Competitive educational programs: towards a concept development. Higher education in Russia, 5, 24-39.

Clark, B.R. (2011). Creation of entrepreneurial universities: organizational transformation trends [Text] / trans. from English by A. Smirnova; State un-ty - Higher School of Economics. - M.: The publishing house of state university - Higher School of Economics, 240 p.

Gibbons, M. (1999). Science's new social contract with society. Nature, 402, 11-18.

Grebenshchikova, E.G. (2011). "The third mission of the university": from the "second type" of knowledge production to the "triple helix" of innovation. / E.G. Grebenshchikova. Yaroslavl Pedagogical Bulletin, 4(1), 270-274.

Humboldt, W. (1998). On the internal and external organization of higher scientific institutions in Berlin: trans. from German. University management: practice and analysis, 3, 28-35.

Itskowitz, G. (2010). Triple helix. Universities - enterprises - state. Innovation in action / G. Itskovits; trans. from English. ed. by A.F. Uvarov. - Tomsk: Publishing house of Tomsk state uninersity of control systems and radio electronics, - $238 \mathrm{p}$. 
REVISTA DE LA UNIVERSIDAD DEL ZULIA. 3e época. Año $11 N^{\circ}$ 31, 2020 Ekaterina Shumik \& Olga Baturina /// Implementation of the Third Mission of the Universities...323-338 DOI: http://dx.doi.org/10.46925//rdluz.31.20

Jaspers, K. (2006). The idea of the university. Trans. from German by T.V. Tyagunova; ed. and trans. H.E. Shparaga; chief ed. M.A. Gusakovsky. - Minsk: BSU, 159 p.

Kiyashchenko, L.P. (2010). Modern forms of knowledge production. Triple spiral of transdisciplinarity: university-government-business [Electronic resource] / L.P. Kiyashchenko. Courier of Rus. academic science and higher education. Electron. Magazine, 67. Access mode: http://courier-edu.ru/courl067/7100.htm.

Kobzev, A.V. (2004). "Oxford" model of the university educational, scientific and innovative complex development / A.V. Kobzev, A.F. Uvarov. Engineering education, 2, 156-159.

Krasnobaeva, I.A. (2007). W. Humboldt's Classical University and Strategic Management of a Modern University / I.A. Krasnobaeva, N.G. Novikova. Service, 4, 144-159.

Kurbatova, N.V. (2014). New state management in the Russian system of higher professional education. Scientific works of DonNTU. Series: economic, 2, 36-45.

Kurochkin, A.V. (2005). Institutionalization of networks in the management of the Russian education system. Politex, 2, 252-261.

Leydesdorff, L. (2006). The Knowledge-Based Economy: Modeled, Measured, Simulated. Boca Raton, FL: Universal Publishers, -405 p.

Martínez de Carrasquero, C. (2019). Responsabilidad social universitaria, transferencia tecnológica y desarrollo endógeno. Estrategias de vinculación comunitaria, Revista Latinoamericana de Difusión Científica, 1 (1), 55-67, http://difusioncientifica.info/index.php/difusioncientifica/article/view/5

Mikhailova, O.V. (2015). Network architecture of public administration: problems of conceptualization and practice: dis. by the Dr. of Polit. Sciences: 23.00.02 / Mihaylova Olga Vladimirovna, $-335 \mathrm{p}$.

Ortega, Y., \& Gasset, H. (2010). University mission. translation from Spanish by M.N. Golubeva, A.M. Korbut; State university - Higher School of Economics. - M.: The publishing house of state university - Higher School of Economics, 144 p.

Prokopiev, V.P. (2000). On the signs of a classical university. University Management: Practice and Analysis, 2, 35-39.

Russian school of education. (2017). The ninth essay. Electronic resource [Text]. Access mode: http://www.bmstu.ru/ vil/kniga/o9.htm. Reference date: 20.04.2017.

Sadovnichy, V.A., Belokurov, V.V., Sushko, V.G., Shikin, E.V. (1995). University Education: An Invitation to Reflection. M., -352 p.

Shmonin, D.V. (2013). Scholastic educational paradigm in the context of historical forms of knowledge translation: to the problem statement. Bulletin of St. Petersburg State University. Series 17: Philosophy. Conflictology. Culturology. Religious studies, 2, 32-37. 
REVISTA DE LA UNIVERSIDAD DEL ZULIA. 3e época. Año 11 Nº 31, 2020 Ekaterina Shumik \& Olga Baturina /// Implementation of the Third Mission of the Universities...323-338 DOI: http://dx.doi.org/10.46925//rdluz.31.20

The third mission of the university. Materials of the portal "Scientific Russia". Electronic resource. URL: https://scientificrussia.ru/articles/tretya-missiya-universiteta. Reference date: 24.07.2019.

Zakharov, I.V. (1994). The mission of the University in European Culture / I.V. Zakharov, E.S. Lyakhovich. - M.: New Millennium, 240 p. 